\title{
Seasonal Variability in Abundance and Vertical Distribution of Parathemisto gaudichaudi (Amphipoda: Hyperiidea) in the North East Atlantic Ocean
}

\author{
R. Williams and D. Robins \\ Natural Environment Research Council, Institute for Marine Environmental Research, Prospect Place, The Hoe, Plymouth PL1 \\ 3DH, Devon, England
}

\begin{abstract}
Vertical distribution, seasonal and diurnal migrations and seasonal variability in abundance of Parathemisto gaudichaudi were investigated using the Longhurst Hardy Plankton Recorder (LHPR) for a 4-y period (1971 to 1974 ) at Ocean Weather Station (OWS) 'India' $\left(59^{\circ} 00^{\prime} \mathrm{N} 19^{\circ} 00^{\prime} \mathrm{W}\right.$ ) in the north-east Atlantic Ocean. The results from this programme were compared with those from the wider geographical coverage of the Continuous Plankton Recorder (CPR) survey and placed in the context of an 18-y series of data (1960 to 1977) from the north-east Atlantic Ocean. The results from the CPR survey showed that $P$. gaudichaudi was widespread over the northern north Atlantic, being most abundant in the Labrador/Greenland current system and in the oceanic area to the west of the UK from June to October, while at OWS 'India' they were most abundant between July and September. The young juveniles (less than $3 \mathrm{~mm}$ in length) accounted for $76 \%$ of the population at OWS 'India'; they were found in the surface waters $(0-50 \mathrm{~m})$ during both day and night. There were considerable changes in the vertical distributions of adults by night and day with amplitudes of diurnal migration of $200 \mathrm{~m}$. These migrations would not have been evident if the population had not been divided into size categories to identify the different behaviour patterns exhibited with age. The population data suggest a 6 - to 8 -week generation time from egg to adult ( $8 \mathrm{~mm}$ ), allowing 2 weeks from egg laying to liberation of young from the brood pouch and a further 4 to 6 weeks to grow from $3 \mathrm{~mm}$ to an adult with a corresponding weight increase of 120 fold from $0.025 \mathrm{mg}(3 \mathrm{~mm})$ to $3.00 \mathrm{mg}(8-13 \mathrm{~mm})$
\end{abstract}

\section{INTRODUCTION}

The principal hyperiids in the plankton of the North Atlantic Ocean are Parathemisto gaudichaudi (Guerin), which predominates in the colder oceanic waters, and P. gracilipes (Norman) over the western and eastern continental shelves (Stephensen, 1925; Grice and Hart, 1962); although Sheader and Evans (1974) consider them to be forms of the same species. $P$. gaudichaudi exhibits a wide range of morphological forms between two extremes, namely $P$. gaudichaudi $f$. compressa and $P$. gaudichaudi $f$. bispinosa. It can moult towards either form, but the factors affecting the degree of development towards either extreme are not fully understood (Sheader and Evans, 1974). The geographical distribution of $P$. gaudichaudi in the northern hemisphere has been summarised by Bowman (1960) and Dunbar (1964); Kane (1966) has shown that it has a circum-polar distribution in the southern hemisphere in the sub-polar west wind drift waters.
Because of its abundance in the plankton and swarming activities (Hardy and Gunther, 1935; Gray and McHardy, 1967) Parathemisto gaudichaudi provides a source of food for a number of larger predators. In the Antarctic Ocean $P$. gaudichaudi forms the food of the sei whale (Nemoto and Yoo, 1970), penguins (Ealey and Chittleborough, 1956) and seals (Siegfried, 1965); it is eaten by horse mackerel off South Africa (Siegfried, 1965), cod in the North Sea and North Atlantic (Brown and Cheng, 1946; Gray and McHardy, 1967) and redfish in the North Atlantic Ocean (Lambert, 1960; Jones, 1970). P. gaudichaudi is a voracious predator, the gut contents generally reflecting the composition of the zooplankton (Siegfried, 1965; Sheader and Evans, 1975); on occasions fish larvae represented over $20 \%$ of its food in the North Sea (Sheader and Evans, 1975).

Parathemisto gaudichaudi was one of the species studied in detail at Ocean Weather Station (OWS) 'India' (59 $00^{\prime} \mathrm{N} 19^{\circ} 00^{\prime} \mathrm{W}$ ) from 1971 to 1975 as part of a 
general study of the plankton ecosystem of the northeast Atlantic Ocean (Williams and Robinson, 1973; Williams, 1974; Williams and Hopkins, 1975, 1976; Williams and Wallace, 1977). This paper aims to describe the seasonal variability in abundance of $P$. gaudichaudi from the 4 years sampling at OWS 'India' and to compare the results with those from the wider geographical coverage of the Continuous Plankton Recorder (CPR) survey of the North Atlantic Ocean (Hardy, 1939; Glover, 1967; Edinburgh Oceanographic Laboratory, 1973).

\section{MATERIALS AND METHODS}

The material used in this work was collected from two sources: (a) the CPR survey of the North Atlantic Ocean (Colebrook, 1975a, b) and (b) oblique hauls taken with the Longhurst-Hardy Plankton Recorder (LHPR) at OWS 'India' (Fig. 1) from March 1971 to October 1974.

The LHPR system (Longhurst et al., 1966; Longhurst and Williams, 1976), with a net and filtering gauze of $280 \mu \mathrm{m}$ nylon mesh, was towed for $1 \mathrm{~h}$ in double oblique hauls between the surface and $500 \mathrm{~m}$ at a combined towing and hauling speed of 3.7 to $4.6 \mathrm{~km} \mathrm{~h}^{-1}$; only the ascent samples were used in this study. Plankton samples were collected at 1-min. intervals which, at the hauling speed of $0.3 \mathrm{~m} \mathrm{~s}^{-1}$, gave approximately one sample every $10 \mathrm{~m}$ depth. Temperature, depth and flow through the mouth of the net were recorded simultaneously with each plankton sample. An average of $500 \mathrm{~m}^{3}$ of water was filtered during each ascent haul and the counts of organisms were converted to numbers $\mathrm{m}^{-2}$ over the depth range sampled.

Hyperiids were extracted from the samples and specimens of Parathemisto gaudichaudi were identified and measured (from the anterior part of the head, excluding the antenna, to the end of the uropods) using

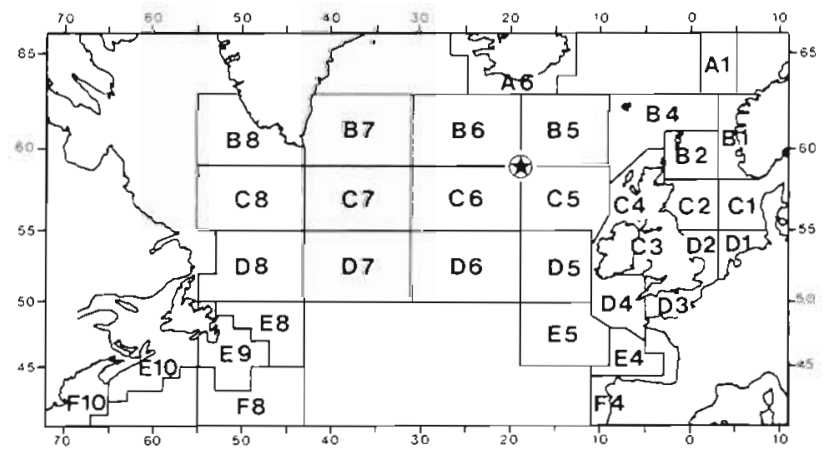

Fig. 1 Chart of the North Atkintic Ocean showing sub-division into the 'standard areas' used in the Continuous Plankton Recorder survey. The position of Ocean Weather Station 'India' $\left(59^{\circ} 00^{\prime} \mathrm{N} 19^{\circ} 00^{\prime} \mathrm{W}\right)$ is shown by a circled star an eye-piece graticule with grid lines of $0.08 \mathrm{~mm}$. They were divided into 5 size categories to assess the population in terms of dry weight biomass and age:

(1) $<3 \mathrm{~mm}$, young juveniles recently released from the brood pouch and those forcibly extruded from the brood pouch by the female striking the net:

(2) 3 to $<8 \mathrm{~mm}$ (designated juveniles);

(3) 8 to $<13 \mathrm{~mm}$;

(4) 13 to $<18 \mathrm{~mm}$;

(5) $\geqq 18 \mathrm{~mm}$.

Categories (3) to (5) were considered to be adult. The mean dry weight was calculated for each size category using methods given by Williams and Robins (1979)

\section{RESULTS}

\section{Geographical Distribution}

The distribution of hyperiid amphipods, from sampling at $10 \mathrm{~m}$ by the CPR, in the North Atlantic Ocean from 1971 to 1974 is shown in Figure 2. The average monthly abundance for each year is based on sampling at monthly intervals in rectangles of $1^{\circ}$ latitude by $2^{\circ}$ longitude (see Edinburgh Oceanographic Laboratory, 1973). The numerical category levels in Figure 2 are the same for all years and show annual mean values of abundance per sample of $3 \mathrm{~m}^{3}$ for each grid rectangle. Some rectangles of the CPR survey area were not sampled monthly throughout the year. Rectangles which were only sampled during the winter months had low annual means but the data can be used to give an overall picture of geographical distribution and an indication of areas of high abundance during the period we sampled at OWS 'India'. Hyperiids were widespread over the survey area but most abundant in the Labrador/Greenland current system and in the oceanic area to the west of the UK.

\section{Seasonal Variability in Abundance}

The mean seasonal variability in abundance of the hyperiids in the CPR Survey from 1958 to 1977 is given in Figure 3. The highest numbers were recorded from June to October with few occurrences at $10 \mathrm{~m}$ in the winter months (December to March). The seasonal variability in abundance of Parathemisto gaudichaudi observed during the 4-y study at OWS 'India' can be compared and placed in the context of the long time series from the CPR in the north-east Atlantic Ocean. To illustrate this comparison we have selected the data from an 18-y period (1960 to 1977) from 3 'standard areas' (Fig. 1, B6, B5 and C5) used in the CPR survey closest to the weather station (Fig. 4). The monthly 

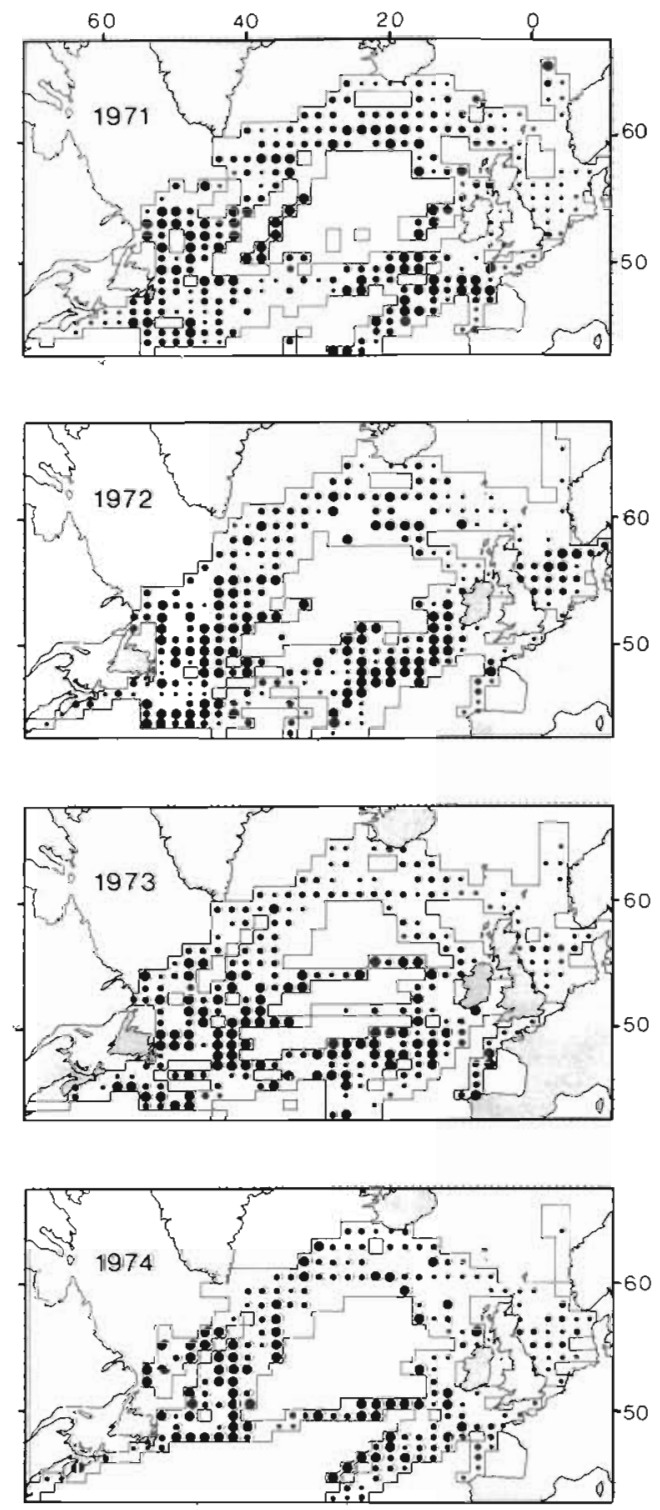

Fig. 2. Hyperiidea. Annual distribution from sampling at $10 \mathrm{~m}$ depth by the Continuous Plankton Recorder. Data for all months sampled were combined to produce charts showing the mean abundance in each of the years from 1971 to 1974 . Samples were assigned to rectangles of $1^{\circ}$ lat. by $2^{\circ}$ long. Rectangle means are represented by 3 graded symbols and indicate the following categories of abundance (average numbers per sample of $\left.3.0 \mathrm{~m}^{3}\right):<1: 1-3:>3$. The absence of symbols (in the sampled area) indicated that hyperiids were not found in Plankton Recorder samples (see, Edinburgh Oceanographic Laboratory, 1973). The boundary of the sampled area is shown by straight lines in the chart

temperature data for the 18-y period, in Figure 4, were derived from data given by Colebrook and Taylor (1979). Although there were considerable year-to-year changes in the levels of abundance of the hyperiids, the seasonal pattern of occurrence was relatively con- stant between years over the period. In all 3 areas the hyperiids were more abundant at $10 \mathrm{~m}$ from June to October with peak numbers in August and September (Fig. 4). The timing of their seasonal occurrence in 'standard areas' B6, B5 and C5 was roughly similar to the timing of $9^{\circ}, 10^{\circ}$ and $11^{\circ} \mathrm{C}$ temperature contours respectively

The seasonal thermal stratification at OWS 'India', 1971 to 1974 , based on daily bathythermographs, temperature readings from Nansen water bottle casts and LHPR thermistor data, were given by Williams et al. (1973-1976). In all 4 years weak stratification was first observed in April; by the end of June the $10^{\circ} \mathrm{C}$ isotherm had penetrated down to at least $100 \mathrm{~m}$ and persisted until October (Fig. 5). The majority of juvenile Parathemisto gaudichaudi were found between the surface and the $10^{\circ} \mathrm{C}$ isotherm (Fig. 5b) while adults were found over a greater depth range between the $9^{\circ} \mathrm{C}$ isotherm and the surface (Fig. 5a). The numbers and biomass under $1 \mathrm{~m}^{2}$ from the surface to $500 \mathrm{~m}$ at 'India' are given in Figure 6 . The numerical data have been converted to dry weight biomass using the following mean dry weight values for each of the following size categories: $<3 \mathrm{~mm}-0.025 \mathrm{mg}, 3$ to $<8 \mathrm{~mm}-0.80 \mathrm{mg}, 8$ to $<13 \mathrm{~mm}-3.00 \mathrm{mg}, 13$ to $<18 \mathrm{~mm}-6.30 \mathrm{mg}$ and $\geqq 18 \mathrm{~mm}-10.00 \mathrm{mg}$. In 1971 and 1972 the dry weight biomass was concentrated during August and September whereas in 1973 and 1974 it was distributed over a longer period (July to September).

\section{Vertical Distribution and Diurnal Migration}

Stephensen (1925) recorded Parathemisto gaudichaudi from the surface to $300 \mathrm{~m}$ in the North Atlantic Ocean while Bigelow (1926) observed the young near the surface in the Gulf of Maine. Kane (1966) has shown that the species aggregated closer to the surface at night and McHardy (1970) found that hyperiids were much more abundant by night than by day over the whole of the areas sampled by the CPR (Fig. 7, from McHardy, 1970). This diurnal migration was more noticeable during the summer months May to September (Fig. 8, Table 1). Numbers of hyperiids in the surface waters $(10 \mathrm{~m})$ were highest during August and September; for night samples the seasonal peak was in August and for day samples it occurred in October (Fig. 8).

Table 1 Parathemisto gaudichaudi. Ratio of night/day densities during 1962-1965

Month: Jan Feb Mar Apr May Jun Jul AugSept Oct Nov Dec $\begin{array}{lllllllllllll}\text { Ratio: } & 3.5 & 4.5 & 2.4 & 4.0 & 7.1 & 8.7 & 5.7 & 9.4 & 5.9 & 3.3 & 4.0 & 5.0\end{array}$ 

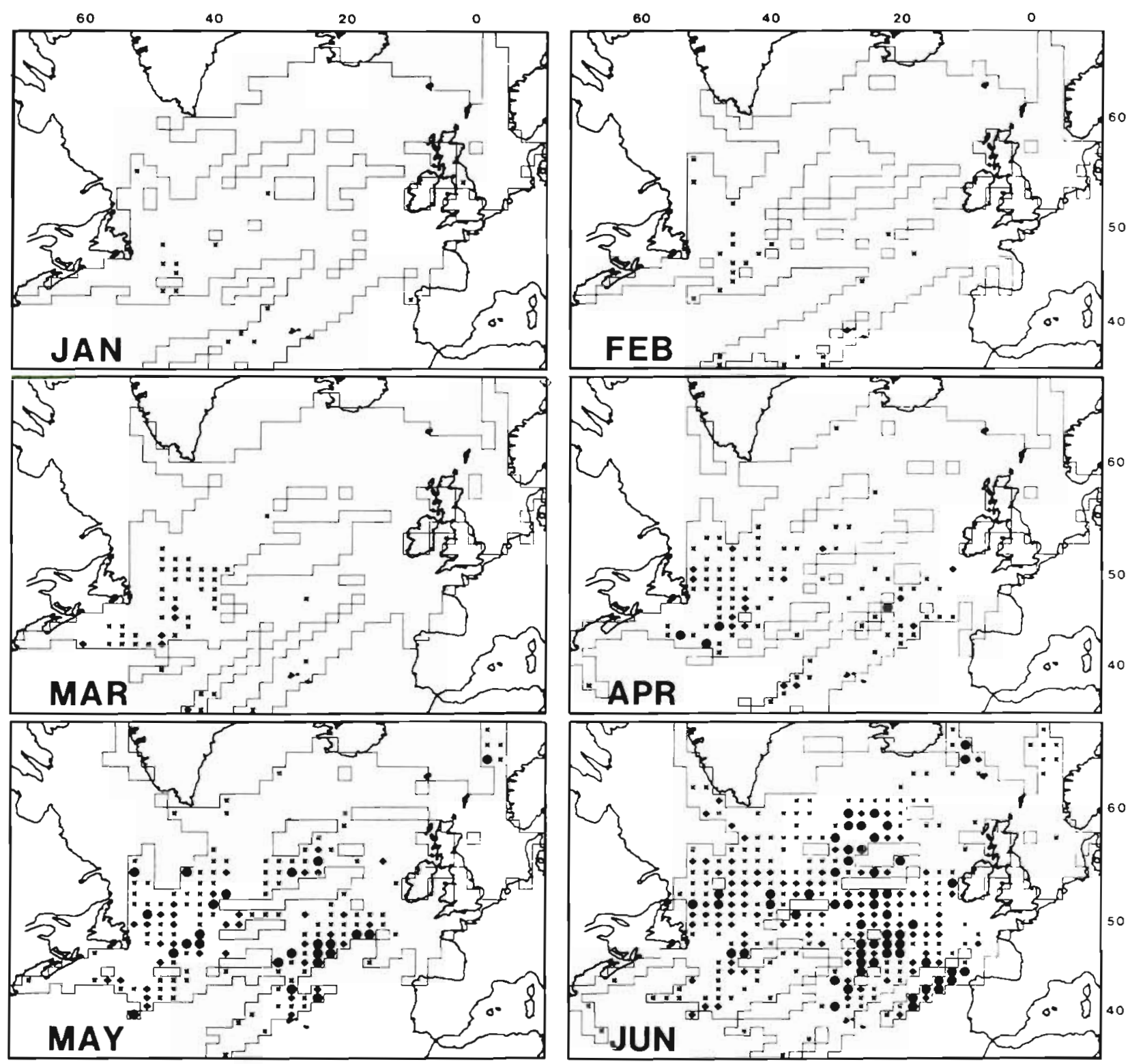

Fig. 3. Hyperiidea. Average monthly distribution from sampling at $10 \mathrm{~m}$ depth by the Continuous Plankton Recorder for the period 1958 to 1977 (see legend to Fig. 2). Rectangle means are represented by 3 graded symbols and indicate the following categories of abundance (average numbers per sample of $3.0 \mathrm{~m}^{3}$ ) : 1.1-<4.3.4.3-11.1 > $>11.1$ The boundary of the sampled area

Eight oblique hauls, from the 98 LHPR hauls collected at OWS 'India', have been used to illustrate the vertical and diurnal migration of the juveniles and adults through their reproductive period in the summer months (Fig. 9). These hauls contained numbers in all our designated size categories, whereas the majority of the LHPR hauls were dominated numerically by young juveniles (Fig 10). Specimens less than $3 \mathrm{~mm}$ had a vertical distribution which is heavily skewed towards the surface, both during day and night (Fig. 9) indicating that the females release their young from the brood pouch at or near the surface. There was one exception
- (28. 8. 72) Figure 9 - where specimens less than $3 \mathrm{~mm}$ appeared at $200 \mathrm{~m}$ in a daytime haul $109.38 \mathrm{~h}$ GMT). Examination of the size and development of individuals indicated that they had been prematurely released from the brood pouch by impact of the ripe adult female (>8 $\mathrm{mm}$ ) with the sampling system. This artefact also accounted for the deeper distributions of young juveniles $(3 \mathrm{~mm})$ seen in Figure 10 . The vertical distribution of the juveniles in Figures 9 and 10 supports McHardy's observations from $10 \mathrm{~m}$ that the youngest stages stay close to the surface $(0-40 \mathrm{~m})$. The juveniles ( 3 to $<8 \mathrm{~mm}$ ) showed some evidence of diur- 

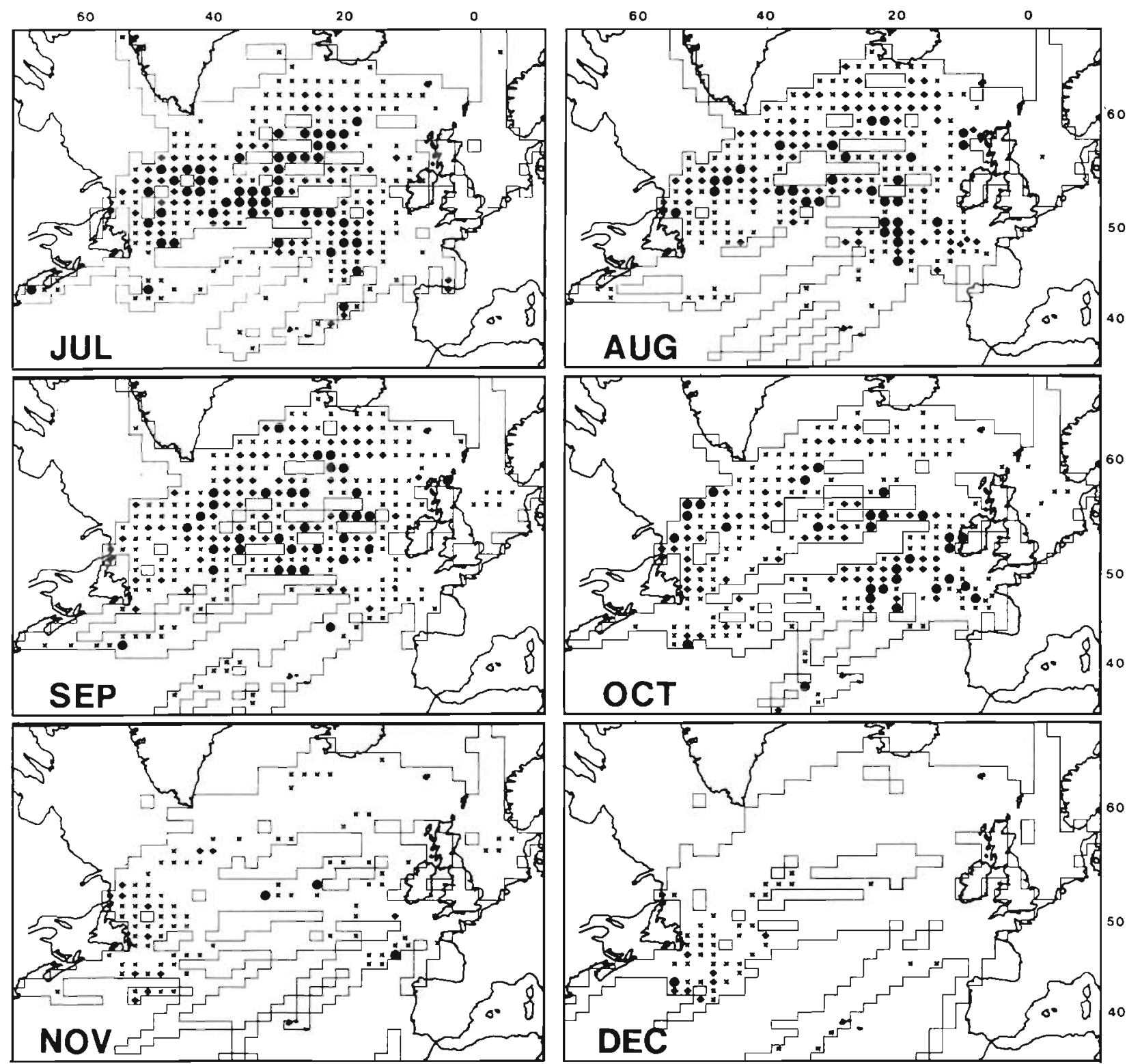

is shown by straight lines in the chart. The absence of symbols in the sampled area indicates that hyperiids were absent or at an occurrence of $<1.1$ per sample per rectangle

nal migrations in the day and night pairs of LHPR hauls (Fig. 9) although the adults ( $\geqq 8 \mathrm{~mm}$ ) exhibited the largest diurnal vertical migration of amplitudes in excess of $200 \mathrm{~m}$ into the upper $40 \mathrm{~m}$ of the water column at night (Figs 9 and 10).

\section{DISCUSSION}

Throughout the 4-y sampling period (1971 to 1974) at OWS India', the results from the oblique hauls showed that the main concentration of the spring/summer population of Parathemisto gaudichaudi occurred in the upper $50 \mathrm{~m}$ of the water column; this was most evident in the case of the young juveniles of less than $3 \mathrm{~mm}$ in length which invariably constituted the majority of the developing population (Fig. 10). Combining the data for all 98 LHPR hauls (day, night) from March 1971 to October 1974, $76 \%$ of the hyperiids were $<3 \mathrm{~mm}$ in length. The vertical distributions shown in Figures 9 and 10 illustrate that the $P$. gaudichaudi - sampled during both day and night, at $10 \mathrm{~m}$, by the Continuous Plankton Recorder - would be indicative of the population present in the epiplankton $(0-200 \mathrm{~m})$. The percentages of the population present in the 0 to 10 -m samples (1971 to 1974 ) were $10.3,16.6$, 
B6
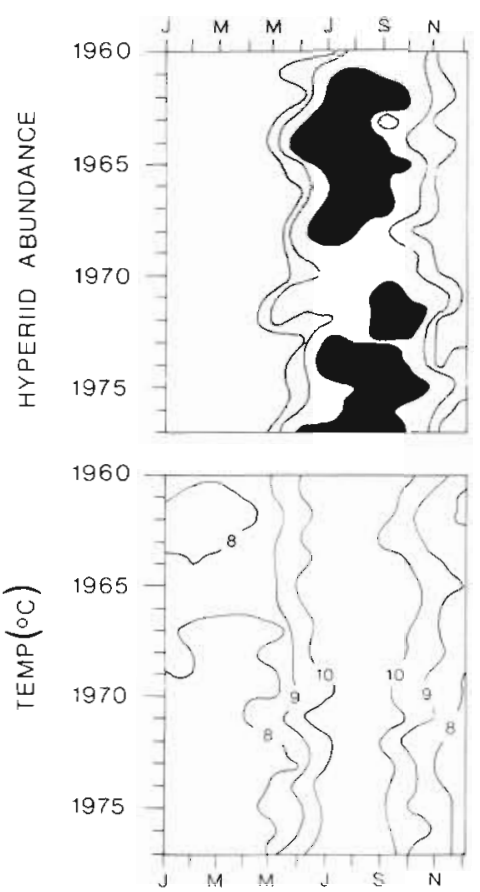

B5
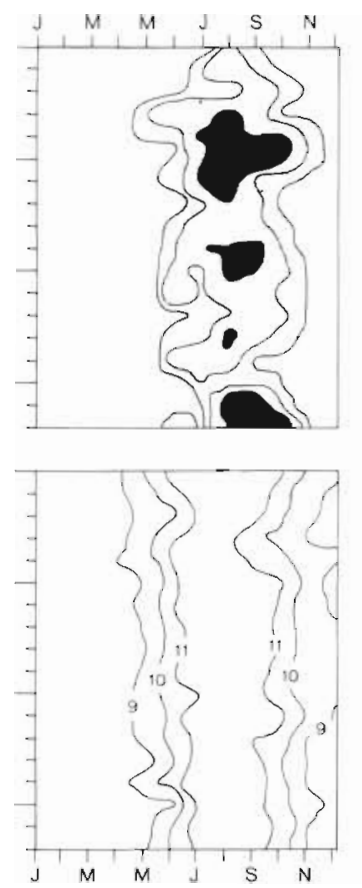

C5
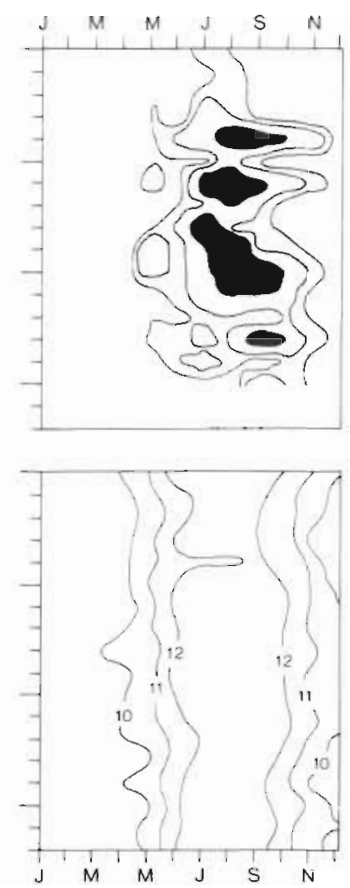

Fig. 4. Seasonal abundance of Hyperiidea from 1960 to 1977 at a depth of $10 \mathrm{~m}$ in 'standard areas B6, B5 and C5 of the Continuous Plankton Recorder Survey (see Fig. 1). The indices of abundance per sample in each 'standard area' were derived by averaging the means for each month in all the rectangles $\left(1^{\circ} \times 2^{\circ}\right)$ in each standard area. Contour levels are 0.5 0.25 and 0.12 per sample of $3.0 \mathrm{~m}^{3}$. The monthly mean sea surface temperatures have been contoured for the 18 years based on data collated by Colebrook and Taylor (1979)

(b)

(a)

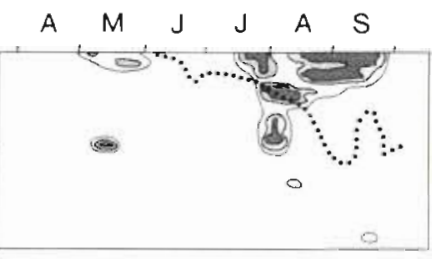

1971

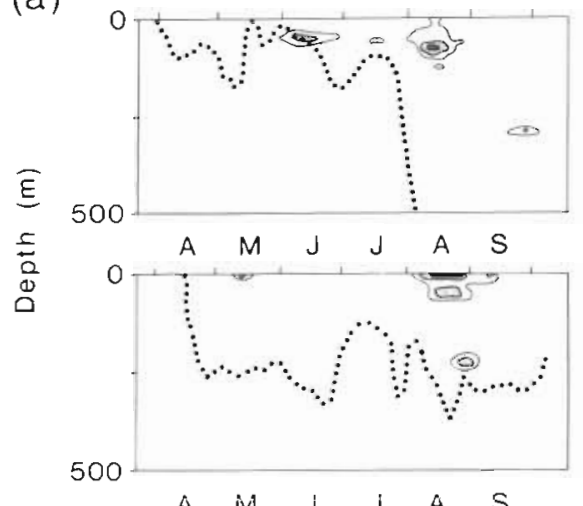

A $M J J A S$

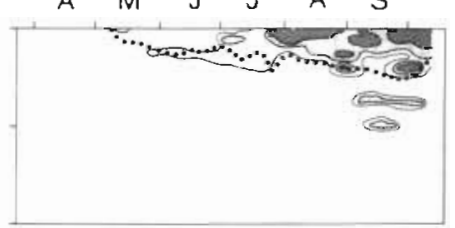

1972

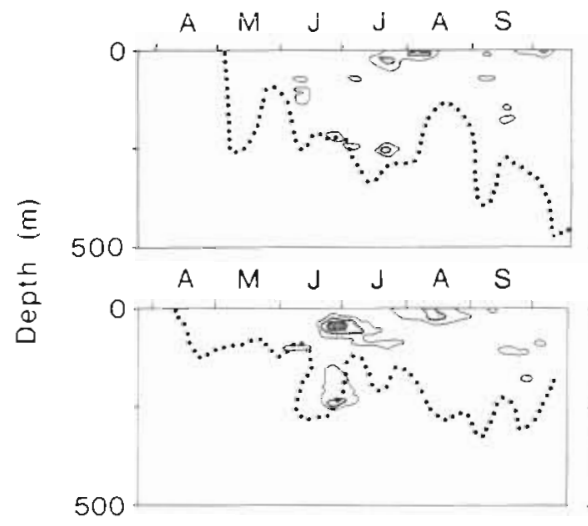

A M J J A S

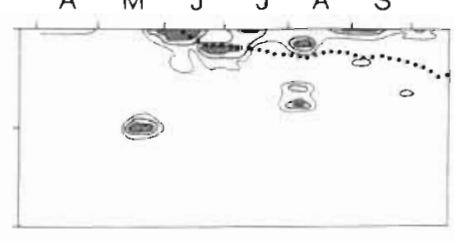

1973

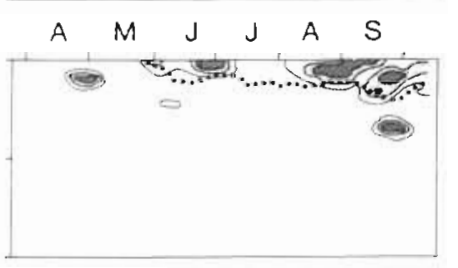

Fig. 5. (a) Parathemisto gaudichaudi. Vertical distribution of adults ( $\geqq 8 \mathrm{~mm}$ ) at Ocean Weather Station 'India' (1971 to 1974) The contour levels of abundance are 4,8 and 16 individuals per $10 \mathrm{~m}^{3}$. The $9^{\circ} \mathrm{C}$ isotherm is shown as a dotted line

(b) Parathemisto gaudichaudi. Vertical distribution of juveniles ( $<8 \mathrm{~mm}$ ) from LHPR oblique hauls at Ocean Weather Station 'India' (1971 to 1974) in the north east Atlantic Ocean. The contour levels of abundance are 4,8 and 16 individuals per $10 \mathrm{~m}^{3}$ The $10^{\circ} \mathrm{C}$ isotherm is shown as a dotted line 

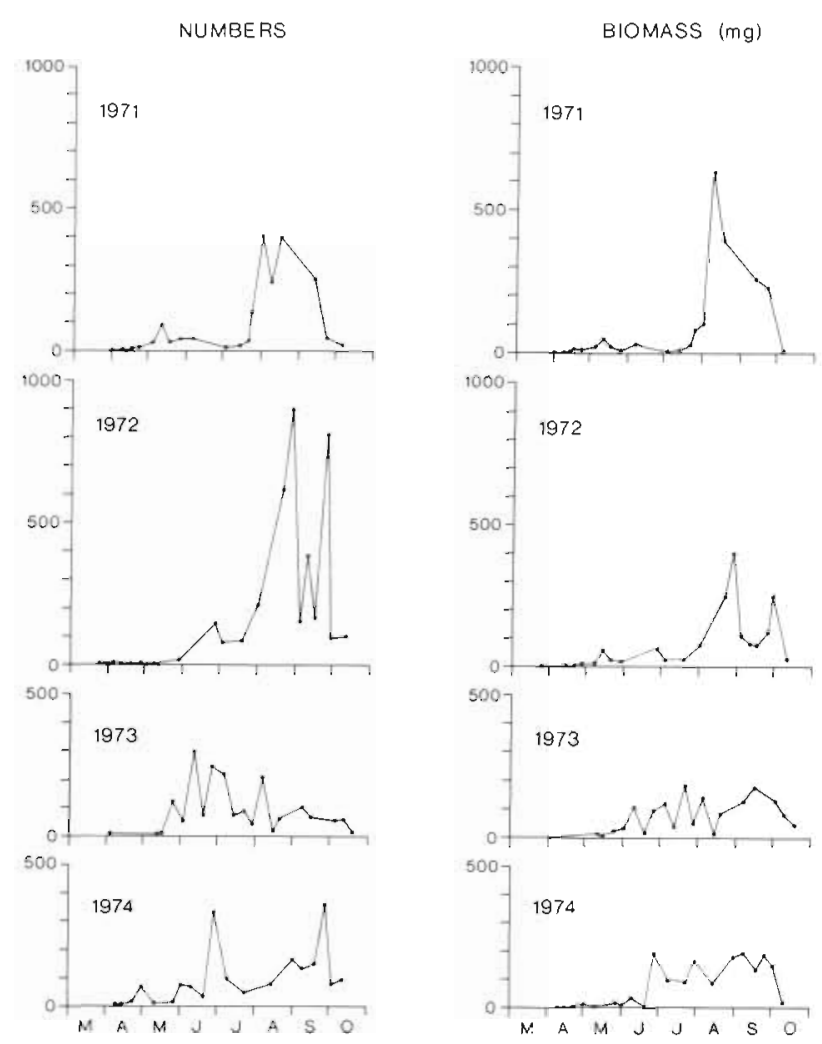

Fig. 6. Parathemisto gaudichaudi. Numbers and dry weight biomass (mg) in the LHPR hauls $(0-500 \mathrm{~m}), 1971$ to 1974 , at Ocean Weather Station 'India' (see Fig. 2)

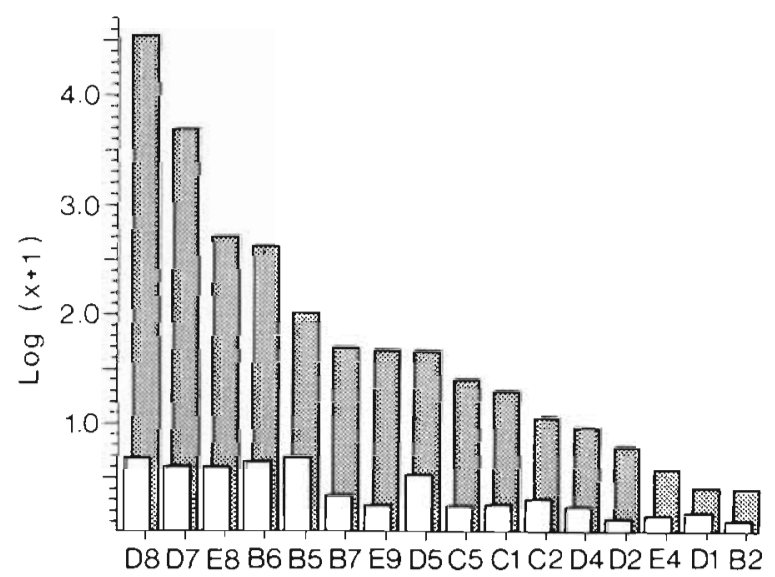

Standard Area

Fig. 7. Average densities of the Hyperiidea at $10 \mathrm{~m}$ in some of the 'standard areas' of the CPR survey (see Fig. 1); $x$ is the mean number of hyperiids per sample in each standard area from 1962 to 1965 from samples taken at night (shaded), by day (unshaded). Data from McHardy 1970 (Ph. D. thesis)

$18.4,10.2$ by day and $27.6,13.6,42.8,20.2$ by night respectively (Fig. 10)

The results from both sampling systems, LHPR and $\mathrm{CPR}$, indicated that maximum numbers occurred from

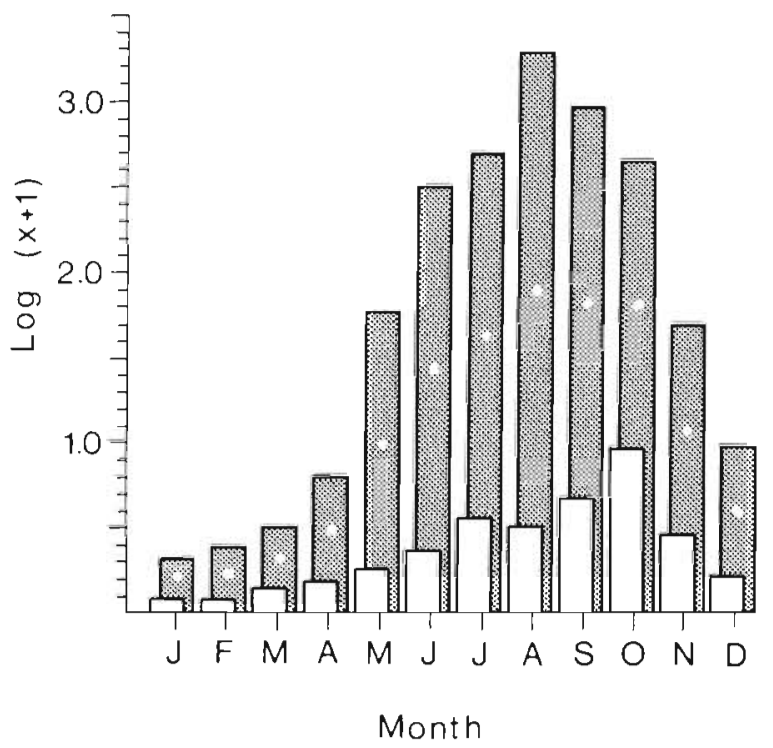

Fig. 8. Average monthly densities of Hyperiidea at $10 \mathrm{~m}$ in the 'standard areas' of the CPR survey given in Figure 7 , in which $\mathrm{x}$ is the mean number per month of hyperiids per sample in each standard area from 1962 to 1965 from samples taken at night (shaded), by day (unshaded) and from all samples (circle). Data from McHardy, 1970 (Ph. D. thesis)

July to September in the north-east Atlantic Ocean. Bigelow (1926) found the summer months to be the main breeding period in the Gulf of Maine although he observed that breeding continued from February to October. Stephensen (1924) concluded that breeding continued throughout the year in the Mediterrannean and the North Atlantic Ocean. At OWS 'India' Parathemisto gaudichaudi $(<3 \mathrm{~mm}$ ) were sampled in large numbers in July of 1971 and 1972 and slightly earlier, in June of 1973 and 1974. In laboratory experiments at $9^{\circ}$ to $10^{\circ} \mathrm{C}$ Sheader (1977) has shown that the duration of embryonic development of $P$. gaudichaudi was 13 to $12 \mathrm{~d}$ from laying to hatching of the eggs plus a further 3-4 d to moult through the 3 development stages in the broad pouch prior to liberation. The liberated juveniles are capable of feeding but still possess yolk reserves which enable them to survive starvation for up to a month at temperatures between $7^{\circ}$ and $10^{\circ} \mathrm{C}$ (Sheader, 1977). At OWS 'India' juveniles were released in the upper $30 \mathrm{~m}$ at temperatures between $10^{\circ}$ and $12^{\circ} \mathrm{C}$; this would result in increased metabolic activity causing a faster utilisation of their energy reserves. We estimate the generation time from egg to young adult $(\geqq 8 \mathrm{~mm}$ ) to be in the region of $6-8$ weeks at OWS 'India', allowing 2 weeks from egg-laying to the liberation of young from the brood pouch, and $4-6$ weeks to grow from $3 \mathrm{~mm}$ to an $8 \mathrm{~mm}$ adult. The corresponding weight increase from $3 \mathrm{~mm}(0.025 \mathrm{mg})$ to an adult of $8-13 \mathrm{~mm}$ ( $3.00 \mathrm{mg})$ would be 120 fold. 


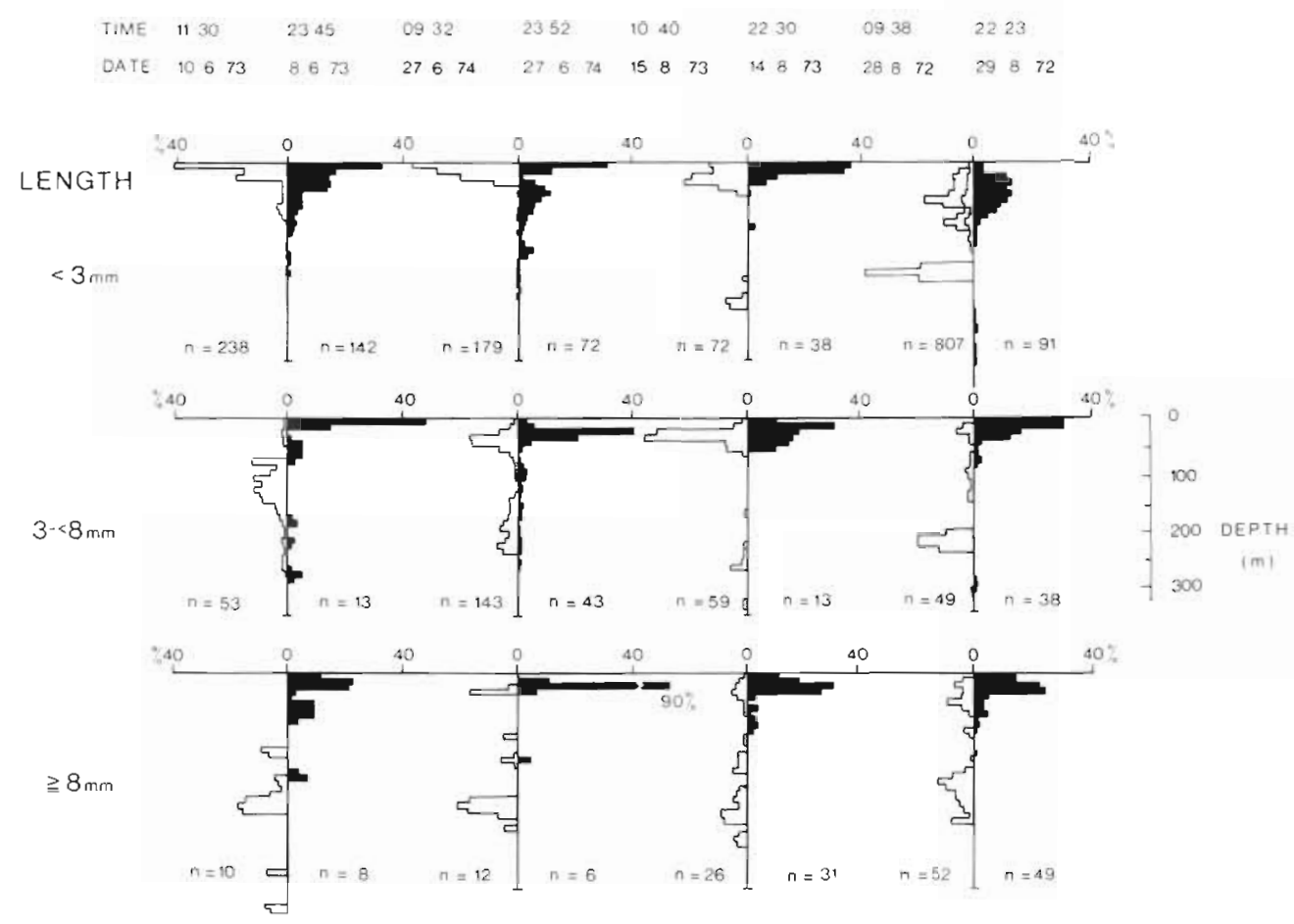

Fig. 9. Parathemisto gaudichaudi. Vertical distribution of 3 size categories $(<3: 3-<8: \geqq 8 \mathrm{~mm})$ from 4 pairs of day and night LHPR oblique hauls at Ocean Weather Station. 'India' The numbers in each day (shaded) and night hauls (black) are plotted in $10 \mathrm{~m}$ depth intervals, as percentages of the total numbers (n) present in each size category. Two histograms are shown for the day haul at 09.30 hrs. GMT on 28. 8. 1972, the unshaded histogram includes the large aggregation of juveniles around $200 \mathrm{~m}$ and the shaded histogram excludes this group of individuals

Mating takes place when an appropriate site of attachment is available; Sheader and Evans (1975) have shown that Hydromedusae are suitable mating sites for Parathemisto gaudichaudi and can be used, also, as food. Aglantha digitale (O. F. Müller) is the most abundant species of Hydromedusae in the northeast Atlantic Ocean accounting for over $80 \%$ by numbers and biomass of all coelenterates ( $R$. Williams and D. V. P. Conway, unpubl.). The period when A. digitale is most abundant precedes the numerical peak of $P$. gaudichaudi by approximately 1 month, roughly corresponding to the time required for the embryonic development and release of the juvenile hyperiids. It therefore seems likely that this hydromedusa plays an important role in the development of the hyperiid population of the north-east Atlantic.

It is necessary to differentiate the Parathemisto population into size categories in order to show the different patterns of diurnal migrations which occur in different age groups. Schulenberger (1978) working with the 10 most abundant hyperiids in the North Pacific Central Gyre concluded, after examining the frequency cumulative percentage curves for similarity with the Kolmogorov-Smirnov (KS) test (Sokal and Rohlf, 1969), that only 2 out of the 10 species exhibited diurnal migrations at the $5 \%(\mathrm{P}<0.05)$ significance level. When the numbers of all size categories of $P$. gaudichaudi in each LHPR haul are summed, the vertical profiles of the total populations are similar to those of the young stages $(<3 \mathrm{~m})$ - the most abundant size category. If Schulenberger had separated each of his species into juveniles and adults we believe that many more cases of diurnal migrations of limited vertical amplitude would have been observed. In any case, the way Schulenberger used the $\mathrm{KS}$ test on his data was incorrect, the test should be carried out on original or summed frequencies from the hauls, and not on mean frequency values which could give erroneous results. In large numbers of plankton species the developmental stages exhibit different migratory behaviour and occupy different depths in the water column. This is clearly shown in differences between the shallower distribution of juvenile $P$. gaudichaudi and the deeper vertical distribution of the older stages.

Adult Parathemisto gaudichaudi, although contributing to a large percentage of the dry weight biomass of the population, especially in the latter part of our sampling periods (September/October), are patchily distributed within the upper $250 \mathrm{~m}$. The large adults are very active and might be able to avoid a sampler towed at approximately $4.0 \mathrm{~km} \mathrm{~h}^{-1}$, so causing an underestimation of the adult population. From 
Fig. 10. Parathemisto gaudichaudi. Vertical distribution of 3 size categories $(<3: 3-<8: \geqq 8)$ in the day and night LHPR oblique hauls at OWS 'India', 1971 to 1974 . (1971 - 19 day and 5 night hauls: 1972 - 20 day and 6 night hauls; 1973 21 day and 4 night hauls; $1974-21$ day and 4 night hauls). The total numbers in the day (shaded) and night hauls (black) are plotted in $10 \mathrm{~m}$ depth intervals, as percentages of the total numbers present in each size category. The percentage of each size category in the total numbers $(\Sigma)$ present are shown
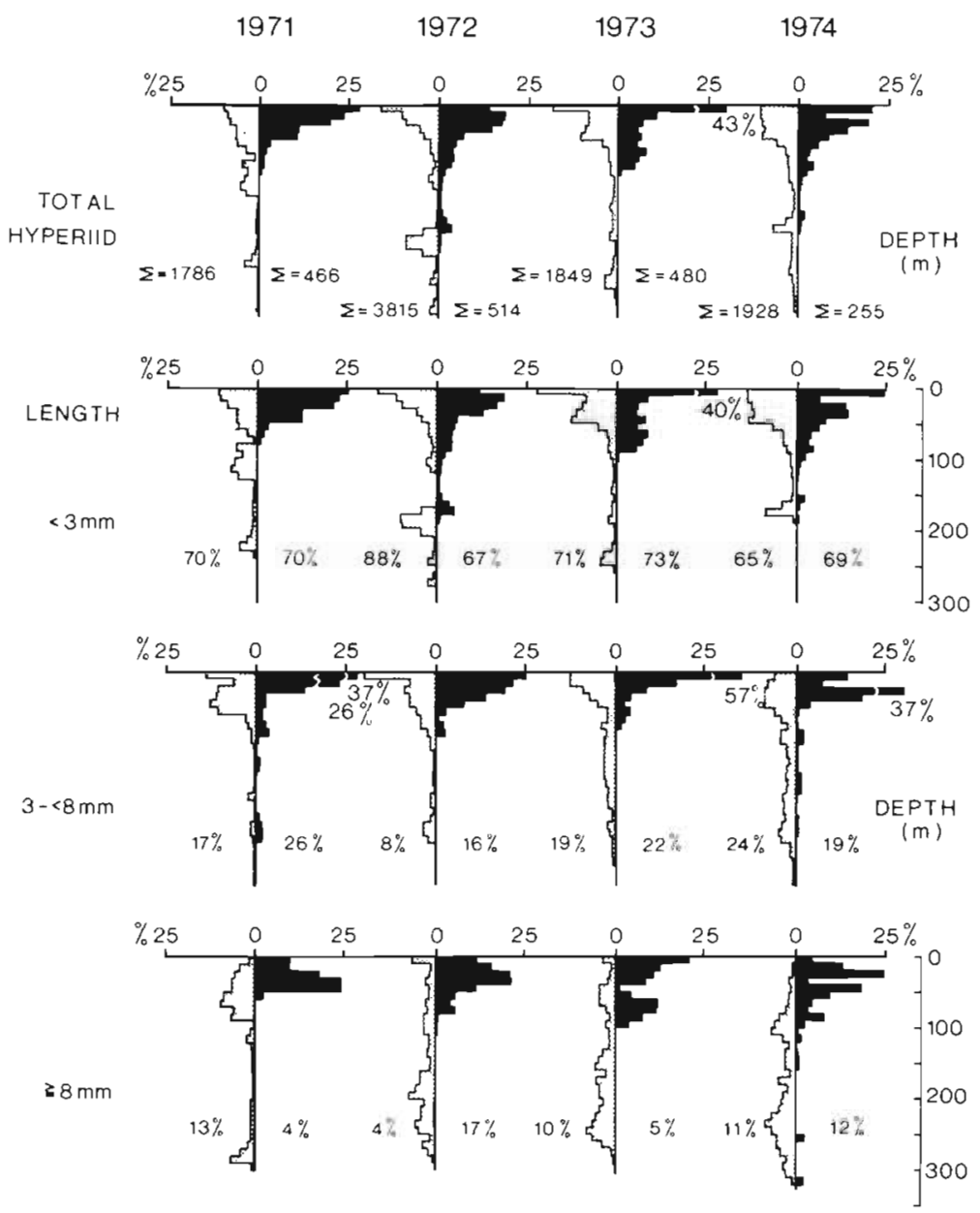

programme. The results of the Continuous Plankton Recorder survey have depended on team work over many years; it forms part of the programme of the Institute for Marine Environmental Research, a component of the Natural Environment Research Council, and is commissioned in part by the Ministry of Agriculture, Fisheries and Food

\section{LITERATURE CITED}

Bigelow, H. B. (1926). Plankton of the offshore waters of the Gulf of Maine. Bull. Bur Fish., Wash. 40: 1-509

Bowman, T. E. (1960). The pelagic amphipod genus Parathemisto (Hyperiidea: Hyperiidae) in the North Pacific and adjacent Arctic Ocean. Proc. U.S. natn. Mus. 112: 343-392

Brown, W. W., Cheng, C. (1946). Investigations into the food of the cod (Gadus callarias L.) off Bear Island and the cod and haddock (G. aeglefinus L.) off Iceland and the Murman coast. Hull Bull. mar. Ecol. 3: 35-71

Colebrook, J. M. (1975a). Automatic data processing methods. Bull. mar. Ecol. 8: 123-142

Colebrook, J. M. (1975b). Computer simulation studies of some aspects of the design of the survey. Bull. mar. Ecol. 8 : 143-166

Colebrook, J. M., Taylor, A. H. (1979). Year-to-year changes in sea-surface temperature, North Atlantic and North Sea, 1948 to 1974 . Deep Sea Res. 26: 825-850
Ocean Weather Ships 'Reporter', 'Surveyor', 'Adviser', and 'Monitor' and the UK Meteorological Office. We also thank our colleagues of the Institute who participated in the OWS 
Dunbar, M. J. (1964). Euphausiids and pelagic amphıpods. Distribution of certain species in the North Atlantic and Arctic Serial Atlas Mar Environ. Folio 6, 2 pp, 8 maps

Ealey, E. H. M., Chittleborough, R. G. (1956). Plankton, hydrology and marine fouling at Heard Island. Interim Rep. Aust. natn. Antarct. Res. Exped. 15: 1-81

Edinburgh Oceanographic Laboratory (1973). Continuous Plankton Records: A plankton atlas of the north Atlantic and North Sea. Bull. mar Ecol. 7: 1-174

Glover, R. S. (1967). The continuous plankton recorder survey of the North Atlantic. Symp. zool. Soc. Lond. 19: 189-210

Gray, J. S., McHardy, R. A. (1967). Swarming of hyperiid amphipods. Nature, Lond. 215: 100

Grice, G. D., Hart, A. D. (1962). The abundance, seasonal occurrence and distribution of the epizooplankton between New York and Bermuda. Ecol. Monogr. 32: 287-309

Hardy, A. C. (1939). Ecological investigations with the continuous plankton recorder: Object, plan and methods Hull Bull. mar. Ecol. 1: 1-57

Hardy, A. C., Gunther, E. R. (1935). The plankton of South Georgia whaling grounds and adjacent waters, 1926-27. 'Discovery' Rep. 11: 1-456

Jones, D. H. (1970). Food, parasites and the reproductive cycle of pelagic redfish (Sebastes mentella Travin) from weather station Alpha in the north Atlantic. Bull. mar. Ecol. 6: 347-370

Kane, J. E. (1966). The distribution of Parathemisto gaudichaudi (Guer) with observations on its life history in the $0^{\circ}$ to $20^{\circ} \mathrm{E}$ sector of the Southern Ocean. 'Discovery' Rep. 34: 163-193

Lambert, D. G. (1960). The food of the redfish Sebastes marinus (L) in the Newfoundland area. J. Fish. Res. Bd Can. 17: 235-243

Longhurst, A. R., Reith, A. D., Bowers, R. E., Seibert, D. L. R. (1966). A new system for the collection of multiple serial samples. Deep Sea Res. 13: 213-222

Longhurst, A. R., Williams, R. (1976). Improved filtration systems for multiple-serial plankton samplers and their deployment. Deep Sea Res. 23: 1067-1073

McHardy, R. A. (1970). Distribution and abundance of hyperiid amphipods in nearsurface waters of the North Atlantic Ocean and North Sea. Ph. D. thesis, University of Edinburgh

Nemoto, T., Yoo, K. I. (1970). The amphipod (Parathemisto gaudichaudi) as a food of the Antarctic Sei whale. Scient. Rep. Whales Res. Inst., Tokyo 22: 153-158
Schulenberger, E. (1978). Vertical distributions, diurnal mgrations and sampling problems of hyperiid amphipods in the North Pacific central gyre. Deep Sea Res. 25: 605-623

Sheader, M., Evans, F. (1974). The taxonomic 'relationships of Parathemisto gaudichaud (Guerin) and P. gracilipes (Norman), with a key to the genus Parathemisto. J. mar biol. Ass. U. K. 54: 915-924

Sheader, M. Evans, F. (1975). Feeding and gut structure of Parathemisto gaudichaudi (Guerin) (Amphipoda: Hyperiidae). J mar. biol. Ass. U. K. 55: 641-656

Sheader, M. (1977). Breeding and marsupial development in laboratory maintained parathemisto gaudichaudi (Amphipoda). J. mar. biol. Ass. U. K. 57: 943-954

Siegfried, W. R. (1965). Observations on the amphipod Parathemisto gaudichaudi (Guer.) off the west coast of South Africa. Zool. Africana 1: 339-352

Sokal, R. R., Rohlf, F. J (1969). Biometry. The principles and practice of statistics in biological research, $W \mathrm{H}$. Freeman, San Fransisco

Stephensen, K. (1924). Hyperiidae-Amphipoda (part 2: Paraphronimidae, Hyperiidae, Dairellidae, Phronimidae, Anchylomeridae). Rep. Dan. oceanogr. Exped. Mediterr. Vol. II (Biology, D.4, part 2), 71-149

Stephensen, K. (1925). Hyperiidae-Amphipoda (part 3: Lycaeopsidae, Pronoidae, Lycaeidae, Brachyscelidae, Oxycephalidae, Parascelidae, Platyscelidae). Rep. Dan. oceanogr Exped. Mediterr., Vol. II (Biology, D.5, Part 3), $151-252$

Williams, R. (1974). Biological sampling at OWS India in 1972. Annls. biol. Copenh. 29: 41-44

Williams, R., Robinson, G. A. (1973). Biological sampling at OWS India $\left(59^{\circ} \mathrm{N} 19^{\circ} \mathrm{W}\right)$ in 1971 . Annls. biol. Copenh. 28: $57-59$

Williams, R., Hopkins, C. C. (1975). Biological sampling at OWS India in 1973. Annls. biol. Copenh. 30: 60-62

Williams, R., Hopkins, C. C. (1976). Biological sampling at OWS India in 1974. Annls. biol. Copenh. 31: 57-60

Williams, R., Wallace, M. A. (1977). Biological sampling at OWS India in 1975. Annls. biol. Copenh. 32: 62-64

Williams, R., Robins, D. (1979). Calorific, ash, carbon and nitrogen content in relation to length and dry weight of Parathemisto gaudichaudi (Amphipoda Hyperiidea) in the North East Atlantic Ocean. Mar. Biol. 52: 247-252 